\title{
Вызванные потенциалы головного мозга (ERPs) в условиях решения лингвистических задач как нейрофизиологический маркер адаптации к приполярному климату
}

\author{
Выскребцов А. ${ }^{1 *}$, Белоногов А. ${ }^{1}$, Таможников С. ${ }^{2}$, Сапрыгин А. ${ }^{2,4}$, Борисова Н. ${ }^{3}$, Карпова А. ${ }^{3}$, \\ Афанасьева Е. ${ }^{3}$, Савостьянов А. ${ }^{1,2,4}$ \\ ${ }^{1}$ Новосибирский государственный университет, ЛБМСПЧ ГИ, Новосибирск, Россия \\ ${ }^{2}$ НИИ физиологии и фундаментальной медицины, Новосибирск, Россия \\ ${ }^{3}$ Северо-Восточный Федеральный Университет им. М.К. Аммосова, Якутск, Россия \\ ${ }^{4}$ Институт изитологии и генетики СО РАН, Новосибирск, Россия \\ *e-mail: a.vyskrebtsov@g.nsu.ru
}

Ключевые слова: климатическая адаптация, личностная тревожность, ERP, распознавание речи

Мотивация и иеель: Распознавание эмоциональной окраски речи является одной из способностей человека, необходимой для регуляции социального поведения. Целью данного исследования было изучение динамики мозговой активности у трудовых мигрантов в ходе их адаптации к приполярным условиям, при помощи анализа мозговых вызванных потенциалов, регистрируемых при распознавании эмоциональной письменной речи.

Meтоды и алгоритмы: В обследовании приняло участие 50 молодых, здоровых жителей поселка Хандыга (арктический район Якутии) и 50 здоровых мигрантов, приехавших в Якутию на длительный срок из южных регионов (Средняя Азия, Африка). Мигранты обследованы дважды сразу же после приезда в Якутию и через полгода после переезда. В эксперименте с одновременной регистрацией ЭЭГ испытуемые выполняли задания по распознаванию грамматической структуры письменных предложений, выражавших разные эмоциональные состояния человека (страх, тревога и агрессия, отнесенные либо к самому участнику, либо к другим людям). Вызванные потенциалы (ERP) оценивались для предложений с разной эмоциональной окраской на разных временных интервалах и в разных областях коры. Были выполнены сопоставления коренного населения и мигрантов, и также сравнения внутри одной группы мигрантов на разных этапах адаптации.

Результаты: Различия между мигрантами и коренным населением были выявлены для амплитуды пиков N400, P300 и Р600. В ходе первого этапа адаптации мигранты показали повышенную активацию правого полушария в сравнении с коренным населением региона. В течение полугода адаптации у мигрантов наблюдается увеличение амплитуды для всех компонентов ERP, связанных с распознаванием речи, что можно рассматривать как результат лучшего усвоения языка.

Заключение: Анализ вызванных потенциалов головного мозга в условиях распознавания эмоциональной речи может быть использован для изучения нейрофизиологических процессов, связанных с социальной адаптацией к новым условиям жизни.

Благодарности: Поддержано грантами РФФИ № 18-415-140021 и № 18-29-13027. Исследование А.Н. Савостьянова и А.Е. Сапрыгина проводятся в рамках бюджетного проекта ИЦиГ СО РАН № 0324-2019-0040-C-01. 